\title{
STOCKHOLM \\ NATURAL RADIOCARBON MEASUREMENTS VI
}

\author{
LARS G. ENGSTRAND
}

Radioactive Dating Laboratory, ${ }^{*}$ Frescati, Stockholm 50, Sweden

The $\mathrm{C}^{14}$ dates given below are a continuation of the work presented in our earlier lists (Stockholm I, II, III, IV, and V). The apparatus and technique are the same as described in Stockholm V.

\section{SAMPLE DESCRIPTIONS}

\section{GEOLOGIC SAMPLES}

\section{Dry fir series}

$$
\text { A. Sweden }
$$

Series is part of a study in Jämtland, central Sweden, on postglacial variations of the upper limit of Pinus forests, caused by climate changes. Samples consist of well-preserved Pinus stamps partly revealed by erosion from the coverage of present vegetation at altitudes just above or below the present-day forest-line (birch-line). Coll. and subm. by Jan Lundqvist, Geol. Survey of Sweden, Stockholm.

Dates for other parts of this work have been published previously (Dry fir series in Stockholm II), and part of the work is also described by G. Lundqvist (1959).

\section{St-581. Stensjön}

$$
4370 \pm 90
$$

At Lake Stensjön $\left(64^{\circ} 11^{\prime} \mathrm{N}\right.$ Lat, $14^{\circ} 34^{\prime} \mathrm{E}$ Long), alt $670 \mathrm{~m}$.

\section{St-817. Kodalshöjden}

$5820 \pm 100$

On the mountain Kodalshöjden $\left(63^{\circ} 38^{\prime} \mathrm{N}\right.$ Lat, $12^{\circ}$ 3870 в.c. $605 \mathrm{~m}$.

\section{St-818. Grönf jället 6}

$4650 \pm 80$

2700 в.C.

On the mountain Grönfjället ( $64^{\circ} 02^{\prime} \mathrm{N}$ Lat, $13^{\circ} 10^{\prime} \mathrm{E}$ Long), alt $680 \mathrm{~m}$.

\section{St-1308. Grönf jället 7}

From $64^{\circ} 02^{\prime} \mathrm{N}$ Lat, $13^{\circ} 11^{\prime} \mathrm{E}$ Long, alt $670 \mathrm{~m}$.

\section{St-1105. Grönf jället 8}

$6325 \pm 85$

4375 в.c.

From $64^{\circ} 02^{\prime} \mathrm{N}$ Lat, $13^{\circ} 11^{\prime}$ E Long, alt $630 \mathrm{~m}$.

\section{St-819. Storkluken 9}

$8600 \pm 150$

6650 в.C.

On the mountain Storkluken ( $63^{\circ} 16^{\prime} \mathrm{N}$ Lat, $12^{\circ} 01^{\prime} \mathrm{E}$ Long), alt $750 \mathrm{~m}$.

* Operated by Royal Acad. of Antiquities, Geol. Survey of Sweden and Univ. of Stockholm. 


\section{St-821. Storkluken 10}

On the mountain Storkluken ( $63^{\circ} 16^{\prime} \mathrm{N}$ Lat, $\left.12^{\circ} 01^{\prime} \mathrm{E} \mathrm{Long}\right)$, alt $650 \mathrm{~m}$.

\section{St-822. Vålöjvalen 13}

$6870 \pm 160$ 4920 в.c.

On the mountain Vålöjvalen $\left(63^{\circ} 02^{\prime} \mathrm{N}\right.$ Lat, $\left.12^{\circ} 49^{\prime} \mathrm{E} \mathrm{Long}\right)$, alt $855 \mathrm{~m}$.

\section{St-823. Smällhögskaftet 15}

$7900 \pm 140$

5950 в.c. $900 \mathrm{~m}$.

On the mountain Smällhögskaftet $\left(63^{\circ} 05^{\prime} \mathrm{N}\right.$ Lat, $12^{\circ} 49^{\prime} \mathrm{E}$ Long $)$, alt

\section{St-825. N. Kyrk $\phi$ stensskaftet 17}

$7950 \pm 120$

6000 в.C.

On the mountain N. Kyrkøstensskaftet $\left(63^{\circ} 11^{\prime} \mathrm{N}\right.$ Lat, $12^{\circ} 48^{\prime} \mathrm{E}$ Long $)$, alt $840 \mathrm{~m}$.

St-1067. S. Kyrkфstensskaftet 16

$5395 \pm 110$

From $63^{\circ} 09^{\prime} \mathrm{N}$ Lat, $12^{\circ} 50^{\prime} \mathrm{E}$ Long, alt $750 \mathrm{~m}$.

\section{St-826. Lillulvån 4}

$7560 \pm 150$

5610 в.c.

At the river Lillulvån $\left(63^{\circ} 09^{\prime} \mathrm{N}\right.$ Lat, $12^{\circ} 22^{\prime} \mathrm{E}$ Long $)$, alt $800 \mathrm{~m}$.

St-1062. Anjeskutan 4 $<\mathbf{2 5 0}$

From $63^{\circ} 45^{\prime} \mathrm{N}$ Lat, $12^{\circ} 42^{\prime}$ E Long, alt $640 \mathrm{~m}$.

St-1307. Anjeskutan 5

From $63^{\circ} 44^{\prime} \mathrm{N}$ Lat, $12^{\circ} 45^{\prime}$ E Long, alt $610 \mathrm{~m}$.

St-1063. Visjövalen 2

From $63^{\circ} 18^{\prime} \mathrm{N}$ Lat, $12^{\circ} 11^{\prime} \mathrm{E}$ Long, alt $680 \mathrm{~m}$.

\section{St-1064. Vålåstugan 14}

From $63^{\circ} 03^{\prime} \mathrm{N}$ Lat, $12^{\circ} 47^{\prime} \mathrm{E}$ Long, alt $880 \mathrm{~m}$.

\section{St-1066. Helags 2}

From $62^{\circ} 57^{\prime} \mathrm{N}$ Lat, $12^{\circ} 24^{\prime}$ E Long, alt $940 \mathrm{~m}$.

\section{St-1102. Helags 3}

From $62^{\circ} 57^{\prime} \mathrm{N}$ Lat, $12^{\circ} 25^{\prime} \mathrm{E}$ Long, alt $900 \mathrm{~m}$.

\section{St-1101. Handöl 7}

From $63^{\circ} 15^{\prime} \mathrm{N}$ Lat, $13^{\circ} 25^{\prime} \mathrm{E}$ Long, alt $670 \mathrm{~m}$.

\section{St-1103. Hjulåsen 12}

From $63^{\circ} 04^{\prime} \mathrm{N}$ Lat, $12^{\circ} 57^{\prime} \mathrm{E}$ Long, alt $745 \mathrm{~m}$.

$6030 \pm 85$ 5080 в.c.

$$
\begin{aligned}
& 7710 \pm 90 \\
& 5760 \text { в.с. }
\end{aligned}
$$

$8030 \pm 115$

6080 в.C.

$6135 \pm 120$

4185 в.C.

$7985 \pm 100$

6035 в.с.

$5665 \pm 85$

3715 B.C.

$4670 \pm 80$

2720 в.c. 


\section{St-1104. Tvärån 5}

From $63^{\circ} 03^{\prime} \mathrm{N}$ Lat, $13^{\circ} 00^{\prime} \mathrm{E}$ Long, alt $765 \mathrm{~m}$.

\section{St-1100. Kloppanåstugan 3}

From $\mathrm{W}$ of the Helags massive $\left(62^{\circ} 54^{\prime} \mathrm{N}\right.$ Lat, $12^{\circ} 13^{\prime} \mathrm{E}$ Long $)$, alt $950 \mathrm{~m}$.

\section{St-1033. Kloppanåstugan 4} $990 \mathrm{~m}$

From $\mathrm{W}$ of the Helags massive $\left(62^{\circ} 54^{\prime} \mathrm{N}\right.$ Lat, $12^{\circ} 13^{\prime} \mathrm{E}$ Long $)$, alt

\section{St-1099. Hammaren 1}

$8385 \pm 105$

6435 в.c.

From the Sylarna massive ( $63^{\circ} \mathrm{N}$ Lat, $12^{\circ} 21^{\prime} \mathrm{E}$ Long), alt $925 \mathrm{~m}$.

\section{St-1028. Hammaren 4}

$8550 \pm 110$

6600 в.C.

From the Sylarna massive ( $62^{\circ} \mathrm{N}$ Lat, $12^{\circ} 19^{\prime} \mathrm{E}$ Long), alt $940 \mathrm{~m}$.

\section{St-1305. Hammaren 5}

$7585 \pm 90$

5635 в.c.

From $63^{\circ} 0^{\prime} \mathrm{N}$ Lat, $12^{\circ} 2 \mathrm{l}^{\prime} \mathrm{E}$ Long, alt $920 \mathrm{~m}$.

\section{St-1027. Ö. Ekorrån 6}

$8365 \pm 100$

6415 в.C. $890 \mathrm{~m}$.

From SE of the Sylarna massive $\left(62^{\circ} 59^{\prime} \mathrm{N}\right.$ Lat, $12^{\circ} 21^{\prime} \mathrm{E}$ Long $)$, alt

\section{St-1029. Nya Sakristian 1}

$$
\begin{aligned}
& 7920 \pm 100 \\
& 5970 \text { в.с. }
\end{aligned}
$$

Near the Helags massive $\left(62^{\circ} 52^{\prime} \mathrm{N}\right.$ Lat, $12^{\circ} 21^{\prime} \mathrm{E}$ Long), alt $880 \mathrm{~m}$.

\section{St-1031. N. Ljungdalsberget 1}

$$
\begin{aligned}
& 3290 \pm 75 \\
& 1340 \text { в.c. }
\end{aligned}
$$

At Ljungdalen $\left(62^{\circ} 51^{\prime} \mathrm{N}\right.$ Lat, $12^{\circ} 48^{\prime} \mathrm{E}$ Long $)$, alt $900 \mathrm{~m}$.

\section{St-1306. N. Ljungdalsberget 2}

$5995 \pm 80$ 4045 в.c.

From $62^{\circ} 52^{\prime} \mathrm{N}$ Lat, $12^{\circ} 48^{\prime} \mathrm{E}$ Long, alt $890 \mathrm{~m}$.

\section{St-1032. Sylsjödammen 5}

At Lake Sylsjön $\left(62^{\circ} 55^{\prime} \mathrm{N}\right.$ Lat, $12^{\circ} 08^{\prime} \mathrm{E}$ Long $)$, alt $910 \mathrm{~m}$.

\section{St-1304. Bunneflätan 1}

From $63^{\circ} 31^{\prime} \mathrm{N}$ Lat, $12^{\circ} 30^{\prime} \mathrm{E}$ Long, alt $640 \mathrm{~m}$.

$4250 \pm 75$

2300 в.с.

\section{Saxvallmyren series}

Dating of pollenanalytical levels and the beginning of peat growth at Saxvallmyren $\left(63^{\circ} 33^{\prime} \mathrm{N}\right.$ Lat, $12^{\circ} 21^{\prime}$ E Long $)$, Jämtland. Subm. by Jan Lundqvist. 


\section{St-1368. Saxvallmyren 1}

$15 \mathrm{~cm}$ below surface. Beginning of Picea curve.

\section{St-1369. Saxvallmyren 2}

$50 \mathrm{~cm}$ below surface. Betula maximum and QM maximum, Climatic optimum.

\section{St-1370. Saxvallmyren 3}

$6760 \pm 80$ 4810 в.c.

$145 \mathrm{~cm}$ below surface. Betula maximum, Alnus maximum, sudden decrease of Pinus.

\section{St-1371. Saxvallmyren 4}

$8365 \pm 110$

$190 \mathrm{~cm}$ below surface. Beginning of the Alnus curve.

St-1372. Saxvallmyren 5 6415 в.c.

Bottom at $200 \mathrm{~cm}$ below surface. Beginning of peat growth.

\section{St-1448. Saxvallmyren 6}

140 to $143 \mathrm{~cm}$ below surface. Dating of a recurrence surface. No. 6 is the upper sample at the recurrence horizon; the lower sample is St-1370, Saxvallmyren 3 .

\section{Ånn series}

Samples from the peatbog at Klocka $\left(62^{\circ} 18^{\prime} \mathrm{N}\right.$ Lat, $12^{\circ} 28^{\prime} \mathrm{E}$ Long $)$, Ånn, Jämtland. All samples were dated for their palynologic interest. Coll. and subm. by Jan Lundqvist.

\section{St-1107. Ānn C 3}

$2110 \pm 80$

Peat from layer with pine stumps, immediately below thin bed of alluvial sand within the peat. The sand layer possibly corresponds to a recurrence surface. A stump from the same level, 30 to $40 \mathrm{~cm}$ below the bog surface, was earlier dated at $3920 \pm 80$ (Stockholm IV, St-601).

\section{St-1185. Ånn C 14}

$$
2280 \pm 75
$$

Sample from $30 \mathrm{~cm}$ below bog surface. Dating of the beginning of the Picea curve in the pollen diagram.

\section{St-1186. Ånn C 15}

$5980 \pm 95$ 4030 в.с.

Sample from $140 \mathrm{~cm}$ below bog surface. Dating of the Betula maximum in the pollen diagram. Corresponding to the Littorina maximum in other parts of Sweden.

\section{St-1090. Önet}

$$
1450 \pm 100
$$

\section{A.D. 500}

Charcoal found in a sand layer below $1.5 \mathrm{~m}$ till, at Önet, Frösön, Jämtland $\left(63^{\circ} 10^{\prime} \mathrm{N}\right.$ Lat, $14^{\circ} 35^{\prime} \mathrm{E}$ Long $)$. Locality is same as the one described by 
A. G. Högbom (1893, Fig. 2), and the sand was supposed to be his submorainic sand, although it is much thinner in the present section. Subm. by Jan Lundqvist.

\section{St-1270. Pilgrimstad}

In a gravel pit $1 \mathrm{~km} \mathrm{~W}$ of Pilgrimstad railway station $\left(62^{\circ} 57^{\prime} \mathrm{N}\right.$ Lat, $15^{\circ} 1^{\prime}$ E Long), Jämtland, several remains of a mammoth and of plants were found in a lacustrine sequence of strata under a thin ground moraine (Kulling, 1945). In 1957 (St-211) a felty, thin bed of Drepanocladus sp. dated $>39,000$ yr. A fragment of wood of Juniperus communis from the above-named lacus. trine beds was collected. Subm. by Oskar Kulling, Geol. Survey of Sweden, Stockholm.

\section{St-1268. Vallsundet 76}

$1730 \pm 170$ A.D. 220

0.5 to $1.0 \mathrm{~m}$ of grey, apparently cultivated earthy gravel with a bottom layer $0.02 \mathrm{~m}$ thick of a black, charcoal-rich sand layer.

St-1269. Vallsundet 77

$1925 \pm 200$

A.D. 25

$0.4 \mathrm{~m}$ of reddish brown sandy gravel with pieces of charcoal in its uppermost part. On a S slope in a gravel pit at Herke, $0.4 \mathrm{~km} \mathrm{NNW}$ of the Vallsundet ferry station $\left(63^{\circ} 10^{\prime} \mathrm{N}\right.$ Lat, 14 ${ }^{\circ} 31^{\prime} \mathrm{E}$ Long $)$, Frösön, Jämtland, was found more than $2 \mathrm{~m}$ of yellow-grey glacifluvial sand and gravel with scattered boulders. Subm. by Oskar Kulling.

\section{St-1011. Långsele}

$>40,000$

Sample from layer of sandy ooze, $1.8 \mathrm{~m}$ thick, below $21 \mathrm{~m}$ till, found in a shaft at the Hjälta HEP station near Långsele $\left(63^{\circ} 11^{\prime} \mathrm{N}\right.$ Lat, $17^{\circ} 0^{\prime} 30^{\prime \prime} \mathrm{E}$ Long), Anngermanland. The fossil content indicates deposition of the ooze in a freshwater lake, and a gradually ameliorating boreal climate, approaching the present one. The fossils and the stratigraphy suggest a geological date to last (Riss-Würm) interglacial (Sundius and Sandegren, 1948). Coll. by R. Sandegren; subm. by E. Fromm, Geol. Survey of Sweden, Stockholm.

\section{St-1320. Grövelsjön 1 \\ $6310 \pm 100$ 4360 в.с. \\ St-1321. Grövelsjön 2

$$
5745 \pm 85
$$$$
3795 \text { в.C. }
$$ \\ Pine stumps from a bog at Lake Grövelsjön $\left(63^{\circ} 7^{\prime} \mathrm{N}\right.$ Lat, $13^{\circ} \mathrm{E}$ Long $)$,} Idre parish, Dalarna. Coll. and subm. by G. Lundqvist.

\section{St-1322. Storsjöberget 3}

\section{St-1323. Storsjöberget 4}

$$
5780 \pm 75
$$

Pine stumps from a bog at Lake Grövelsjön $\left(62^{\circ} 5^{\prime} \mathrm{N}\right.$ Lat, $12^{\circ} 1^{\prime} \mathrm{E}$ Long), Idre parish, Dalarna. 


\section{St-1454. Strimasund 3}

Pine cones from Strimasund, Tärnaby parish $\left(66^{\circ} 10^{\prime} \mathrm{N}\right.$ Lat, $14^{\circ} 53^{\prime} \mathrm{E}$ Long), Västerbottens län. Subm. by G. Lundqvist.

\section{Hällesjö series}

Peat samples from Hällesjö, Jämtland $\left(62^{\circ} 52^{\prime} \mathrm{N}\right.$ Lat, $16^{\circ} 13^{\prime} \mathrm{E}$ Long $)$. Samples provide a comparison between De Geer's time schedule and von Post's pollen analytic method. Subm. by C. G. Wenner, Dept. of Quaternary Geol., Univ. of Stockholm.

\section{St-1179. Hällesjö I A}

$8595 \pm 100$

\section{St-1180. Hällesjö I B}

6645 в.с.

\section{St-1181. Hällesjö I C}

$$
8665 \pm 115
$$

6715 в.C.

\section{St-1182. Hällesjö II A}

$8735 \pm 115$

6785 в.C.

\section{St-1183. Hällesjö II B}

\section{Björneåborg series}

Dating of a recurrence surface in the peat bog at Björneåborg, $17 \mathrm{~km}$ WSW from the church of Färila, province Gävleborg $\left(61^{\circ} 42^{\prime} \mathrm{N} \mathrm{Lat}, 15^{\circ} 33^{\prime}\right.$ E Long). Subm. by G. Lundqvist.

\section{St-1088. Björneåborg 15}

Humified peat immediately above the recurrence surface, $150 \mathrm{~cm}$ below the bog surface.

\section{St-1089. Björneåborg 16}

$2130 \pm 75$

$160 \mathrm{~cm}$ below the bog surface.

\section{St-1059. Mårtenstorp}

\section{0 в.C.}

$$
\begin{gathered}
2175 \pm 65 \\
225 \text { в.c. }
\end{gathered}
$$

Charcoal found among slag in an ancient iron manufacturing furnace, Osmund forge at Ramsberg parish, Örebro ( $59^{\circ} 47^{\prime} \mathrm{N} \mathrm{Lat}, 15^{\circ} 30^{\prime} \mathrm{E}$ Long). Slag is found so far from nearest stream that furnace cannot have been driven with water power. Probably it is a very primitive furnace, older than oldest historically known furnaces (from the 15th century), and thus dating will throw light upon the oldest iron manufacturing in this ore district. Date is of special importance in connection with other similar samples, e.g. the Osmund forges series (St-640 to 644 and St-707). Coll. and subm. by Karl Erik Nergård, Grängesberg.

\section{St-1419. Mårtensön 1}

Wood found $2.9 \mathrm{~m}$ below land surface and at same level as the lake Siljan. Coll. by H. Holner. 
St-1457. Mårtensön 6

Wood from Mårtensön (61 $6^{\prime} \mathrm{N}$ Lat, $14^{\circ} 36^{\prime} \mathrm{E}$ Long), Orsa parish, Dalarna. Subm. by G. Lundqvist and P. Nordquist, Orsa.

\section{St-1026. Furuvik $1\left(\mathrm{Ca} \mathrm{CO}_{3}\right)$}

\section{St-1030. Furuvik 1 (Organic)}

\section{St-1039. Furuvik 2 (Organic)}

$$
\begin{aligned}
& 28,700 \pm 1100 \\
& 26,750 \text { в.C. } \\
& 12,970 \pm \mathbf{2 6 0} \\
& 11,020 \text { в.c. }
\end{aligned}
$$

$11,270 \pm 120$

Clay from Furuvik $\left(60^{\circ} 39^{\prime} \mathrm{N}\right.$ Lat, $17^{\circ} 18^{\prime} \mathrm{E}$ Long), province Gävleborg. Subm. by G. Lundqvist.

\section{St-1514. Karlsborg peat}

$$
\begin{aligned}
& 8200 \pm 100 \\
& 6250 \text { в.c. } \\
& 9280 \pm 180 \\
& 7330 \text { в.c. }
\end{aligned}
$$

St-1480. Karlsborg wood

Log imbedded in Phragmites peat and covered with sand, ca. $1 \mathrm{~m}$ above the present surface of Lake Vättern below the level of Ancient Lake Vättern (F V G) that is about $93 \mathrm{~m}$ above sealevel, at Karlsborg $\left(58^{\circ} 32^{\prime} \mathrm{N}\right.$ Lat, $14^{\circ}$ $30^{\prime}$ E Long), Västergötland. Investigation made in order to date the curve of land uplift. Subm. by Erik Nilsson, Västerhaninge, Geol. Survey of Sweden, Stockholm.

\section{St-1060. Kolebäcks ugn I}

Charcoal from the furnace.

$$
345 \pm 60
$$

\section{St-1061. Kolebäcks ugn II}

A.D. 1605

Charcoal from an area around the furnace, imbedded in slag from ancient manufacturing furnaces at Fritsla $\left(57^{\circ} 33^{\prime} \mathrm{N}\right.$ Lat, $12^{\circ} 49^{\prime} \mathrm{E}$ Long $)$, Västergötland. For other old production of iron in SW Sweden see St-640 to 644, Stockholm IV. Coll. and subm. by Gösta Ahlström, Borås.

\section{Snöromsmossen series, Stockholm}

Samples of peat from Snöromsmossen, Nacka $\left(59^{\circ} 20^{\prime} \mathrm{N}\right.$ Lat, $18^{\circ} 10^{\prime} \mathrm{E}$ Long), Stockholm län. Coll. and subm. by Jozef Praglowski, Dept. of Quaternary Research, Univ. of Stockholm.

St-1522. Snöromsmossen 43

St-1521. Snöromsmossen 45

$$
\begin{array}{r}
920 \\
\text { A.D. } 1030 \\
875 \\
\text { A.D. } 1075
\end{array}
$$

\section{Dagsmosse series}

Samples of peat collected in a profile of the raised bog Dagsmosse $\left(57^{\circ} 19^{\prime}\right.$ N Lat, 14. $42^{\prime}$ E Long), SW of Lake Tåkern, Östergötland, in order to date some features in the pollen diagram from the same section.

St-1187. Dagsmosse 1, untreated $1155 \pm 70$ A.D. 795 


\section{St-1373. Dagsmosse 1, pretreated}

$$
\begin{array}{r}
1280 \\
\text { A.D. } 670
\end{array}
$$

Sphagnum peat, immediately above a well-marked RY (probably RY III), depth 195 to $199 \mathrm{~cm}$. St-1187 was untreated; St-1373 was another collection, pretreated with $2 \% \mathrm{NaOH}$ solution and $\mathrm{HCl}$ solution.

St-1188. Dagsmosse 2, untreated

St-1374. Dagsmosse 2, pretreated

$$
\begin{array}{r}
1505 \pm 70 \\
\text { A.D. } 445 \\
2140 \pm 70 \\
190 \text { в.c. }
\end{array}
$$

Sphagnum peat, 220 to $225 \mathrm{~cm}$ depth, at the rise of the Picea curve. St-1188 was untreated; St-1374 was another collection, pretreated with $2 \%$ $\mathrm{NaOH}$ solution and $\mathrm{HCl}$ solution.

\section{St-1189. Dagsmosse 3, untreated}

\section{St-1375. Dagsmosse 3, pretreated}

$$
\begin{aligned}
& 3425 \pm 70 \\
& 1475 \text { в.c. } \\
& 3125 \pm 105 \\
& 1175 \text { в.c. }
\end{aligned}
$$

Sphagnum peat below very humified pine forest peat, 258 to $260 \mathrm{~cm}$ depth. St-1189 was untreated; St-1375 was another collection, pretreated with $2 \% \mathrm{NaOH}$ solution and $\mathrm{HCl}$ solution.

\section{St-1190. Dagsmosse 4, untreated}

$$
\begin{aligned}
& 3075 \pm 80 \\
& 1125 \text { в.c. } \\
& 3340 \pm 115 \\
& 1390 \text { в.c. } \\
& 3160 \pm 105 \\
& 1210 \text { в.c. }
\end{aligned}
$$$$
\text { St-1190 B. Dagsmosse 4, untreated }
$$$$
\text { St-1376. Dagsmosse 4, pretreated }
$$

Sphagnum peat, 280 to $284 \mathrm{~cm}$ depth, at a level probably assumed to correspond to the beginning of the settlement in the pile-dwelling at Alvesta. St-1190 was untreated; St-1190 B was also untreated and from same collection as St-1190; St-1376 was another collection, pretreated with $2 \% \mathrm{NaOH}$ solution and $\mathrm{HCl}$ solution.

\section{St-1191. Dagsmosse 5, untreated}

\section{St-1191 B. Dagsmosse 5, untreated}

\section{St-1377. Dagsmosse 5, pretreated}

$$
\begin{aligned}
& 3650 \pm 80 \\
& 1700 \text { в.C. } \\
& 3460 \pm 110 \\
& 1510 \text { в.C. } \\
& 4530 \pm 80
\end{aligned}
$$

Magnocaricetum peat, 345 to $348 \mathrm{~cm}$, at the zone VII/VIII boundary. St-1191 was untreated; St-1191 B was untreated and from the same collection as St-1191. St-1377 was another collection, pretreated with $2 \% \mathrm{NaOH}$ solution and $\mathrm{HCl}$ solution.

St-1192. Dagsmosse 6, untreated

$6255+90$ 4305 в.c. 


\section{St-1347. Dagsmosse 6, pretreated}

Magnocaricetum peat, 452 to $457 \mathrm{~cm}$ depth, at the beginning of the Tilia curve. St-1192 was untreated; St-1347 was another collection, pretreated with $2 \% \mathrm{NaOH}$ solution and $\mathrm{HCl}$ solution.

St-1193. Dagsmosse 7, untreated

St-1193 B. Dagsmosse 7, untreated

\section{St-1378. Dagsmosse 7, pretreated}

$7545 \pm 90$ 5595 в.c.

$7525 \pm 100$ 5575 в.C.

$7585 \pm 130$

5635 в.c.

Phragmites peat, 570 to $575 \mathrm{~cm}$ depth, at the beginning of the Alnus curve. St-1193 was untreated; St-1193 B was untreated and from the same collection as St-1193. St-1378 was another collection, pretreated with $2 \% \mathrm{NaOH}$ solution and $\mathrm{HCl}$ solution.

\section{Viskan series}

Various kinds of peat, "pitchy soil," and mud with various amounts of detritus from the Viskan valley in Västergötland and Halland (between $57^{\circ} 15^{\prime}$ $\mathrm{N}$ Lat, $12^{\circ} 19^{\prime} 30^{\prime \prime} \mathrm{E}$ Long and $57^{\circ} 24^{\prime} \mathrm{N}$ Lat, $12^{\circ} 31^{\prime} \mathrm{E}$ Long). Investigation made in order to date certain important epeirogenic events in Finiglacial and Postglacial time, and in order to make age of the different shorelines and their relative relations clear. Coll. and subm. 1963-1964 by N.A. Mörner, Univ. of Stockholm, Dept. of Quaternary Research.

\section{St-1208. LP 45 BP 1196 (B 1)}

Black clayey mud ("pitchy soil").

\section{St-1207. LP 39 BP 1233 (B 4)}

Phragmites mud.

\section{St-1290. LP 40 B 107}

Black clayey mud ("pitchy soil").

\section{St-1280. LP 14 BP 217 (B 100)}

Brushwood peat.

\section{St-1206. LP 4 BP 22 (B 5)}

Phragmites mud with layers of Amblystegium peat.

\section{St-1291. LP 10 B 101 Kattunga A}

Amblystegium peat (also other plant remains).

\section{St-1292. LP 10 B 101 Kattunga $B$}

Highly humified peat.
$7795 \pm 150$ 5845 в.c.

$9305 \pm 110$ 7355 в.с.

$9280 \pm 110$ 7330 в.с.

$7795 \pm 90$ 5845 в.c.

$7750 \pm 110$ 5800 в.c.

$4890 \pm 90$ 2940 B.c. $7605 \pm 90$ 5655 в.c. 
St-1463. B 104

Black muddy clay ("pitchy soil").

St-1531. B 95 : 1

Detritus mud.

St-1532. B 95 : 2

Magnocaricetum peat.

St-1533. B 95 : 3

Highly humified peat (Carez, Phragm.).

St-1534. B 95 : 4

Detritus mud.

St-1528. B 99 : 1

Magnocaricetum peat.

St-1529. В 99 : 2

Parvocaricetum peat.

St-1530. B 99 : 3

Clayey mud.

St-1491. BP 300 : 1

Muddy clay.

St-1498. BP 300 : 2

Muddy clay/clayey mud.

St-1492. BP 300 : 3

Clayey mud.

St-1500. BP $300: 4$

Mud.

St-1502. BP 629 : 1

Muddy clay.

St-1503. BP $629: 3$

Muddy clay.

St-1496. BP 629 : 2

St-1505. BP 629 : 4

Mud.

$$
\begin{aligned}
& \mathbf{7 7 7 5} \pm 100 \\
& \mathbf{5 8 2 5} \text { в.c. } \\
& \\
& \mathbf{7 7 3 0} \pm \mathbf{1 6 5} \\
& \mathbf{5 7 8 0} \text { в.c. } \\
& \\
& \mathbf{7 5 4 5} \pm \mathbf{1 5 0} \\
& \mathbf{5 5 9 5} \text { в.c. } \\
& \\
& \mathbf{7 5 8 5} \pm \mathbf{1 9 0} \\
& \mathbf{5 6 3 5} \text { в.c. }
\end{aligned}
$$

$12,165 \pm 230$

10,215 в.c.

$7985 \pm 155$

6035 в.c.

$8980 \pm 170$

7030 в.с.

$8620 \pm 170$

6670 в.с.

$15,190 \pm 260$

13,240 в.c.

$9810 \pm 100$

7860 в.с.

$7650 \pm 100$

5700 в.с.

$6970 \pm 90$

5020 в.c.

$12,240 \pm 240$

10,290 в.c.

$10,550 \pm 145$

8600 в.c.

$9510 \pm 135$

7560 в.с.

$7065 \pm 145$

5115 в.c. 
St-1497. BP 1561 : 1

Coarse-detritus mud.

St-1511. BP 1540 : 2

Detritus mud.

St-1510. BP 1540 : 1

Coarse-detritus mud.

\section{St-1464. B 34}

Muddy clay/clayey mud.
$9155 \pm 110$

7205 в.с.

$10,400 \pm 170$

8450 в.c.

$9330 \pm 200$

7380 в.с.

$7800 \pm 330$

5850 в.c.

\section{Segebro series}

Samples of marine clay-gyttja and wood from the Segebro-Sjölunda $\left(55^{\circ}\right.$ $37^{\prime} \mathrm{N}$ Lat, $13^{\circ} 04^{\prime} \mathrm{E}$ Long to $55^{\circ} 38^{\prime} \mathrm{N}$ Lat, $13^{\circ} 03^{\prime} \mathrm{E}$ Long) area $\mathrm{NE}$ of Malmö, Scania, collected in order to make a contribution to the study of the Littorina-Tapes transgression at Malmö and to date some submerged Mesolithic dwelling-places. Subm. by Alf Sigling, Dept. of Quaternary Geology, Univ. of Lund.

\section{St-1194. Segebro P 14}

$7795 \pm 100$ 5845 в.c.

Clay-gyttja from level 190 to $195 \mathrm{~cm}$ (alt -3.20 to $-3.25 \mathrm{~m}$ ) in profile 14 (coll. A. Sigling). In the pollen-diagram this level corresponds to the boundary between pollen zones AT-1 and AT-2 in the Scanian pollen zone system

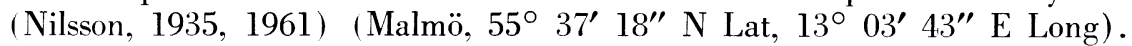
Comment: this sample (and St-1195) collected in order to test fitness of the marine clay-gyttja (in a former river mouth) for $\mathrm{C}^{14}$ dating. $\mathrm{C}^{14}$ ages are more than $500 \mathrm{yr}$ older than the pollenanalytical results indicate. Although marine influence may be responsible, it is also possible that there has been redeposition of material by the river.

\section{St-1195. Segebro $P 18$}

Clay-gyttja from level 195 to $200 \mathrm{~cm}$ (alt -0.75 to $-0.80 \mathrm{~m}$ ) in $\mathrm{P} 18$ (ASg). Below level AT-2e (an early part of the late Atlantic period). (Malmö, $55^{\circ} 37^{\prime} 20^{\prime \prime} \mathrm{N}$ Lat, $13^{\circ} 03^{\prime} 39^{\prime \prime}$ E Long.)

\section{St-1196. Sjölunda P 37}

Oak (heart) wood from submarine peat (alt $-3.7 \mathrm{~m}$ ), which belongs to oldest part of pollen zone AT-1. (Malmö, $55^{\circ} 38^{\prime} \mathrm{N}$ Lat, $13^{\circ} 02^{\prime} 46^{\prime \prime}$ E Long.) Comment: the time gap between peat and overlaying marine clay-gyttja is an unsolved problem, even if the clay-gyttja samples date the pollen diagram. But the oak has been growing at the place and probably dates the peat.

\section{Sand drift series}

Eolian sand drift of southern part of Swedish $\mathbb{W}$ coast. Coll. and subm. by Erik Mohrén, Geol. Survey of Sweden, Stockholm. 
St-1198. M 138 : 62

$1815 \pm 65$

A.D. 135

Fine sand, rich in humus, $80 \mathrm{~cm}$ below an (artificial) surface, at Snöstorp, Halland ( $56^{\circ} 39^{\prime} 35^{\prime \prime}$ N Lat, $12^{\circ} 56^{\prime} 17^{\prime \prime}$ E Long).

St-1199. M 130 : 62

$1065 \pm 95$

A.D. 885

Fine sand, somewhat ferruginous, $40 \mathrm{~cm}$ below an (artificial) surface, at Snöstorp, Halland ( $56^{\circ} 39^{\prime} 35^{\prime \prime}$ N Lat, $12^{\circ} 56^{\prime} 17^{\prime \prime}$ E Long).

St-1200. Stora Haverdalsdynen III

$445 \pm 140$

A.D. 1505

Eolian medium sand with $\mathrm{dy}$ and gyttja (necron-mud), at Harplinge, Halland (56 $41^{\prime} 20^{\prime \prime} \mathrm{N}$ Lat, $12^{\circ} 42^{\prime} 29^{\prime \prime} \mathrm{E}$ Long). Coll. 1950 by Gunnel Linnman, Dept. of Quaternary Geol., Univ. of Stockholm.

\section{St-1201. Yngsjö 9}

$9540 \pm 120$ 7590 в.с.

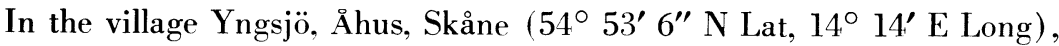
a thin layer $(5$ to $10 \mathrm{~cm})$ of black sandy peat was found in a drilling core. Peat was covered by $9 \mathrm{~m}$ of sand, marine and/or eolian. Peat probably represents a land surface, previous to or contemporaneous with the beginning Ancylus transgression of the Baltic. Sample taken 5 to $6 \mathrm{~m}$ below sealevel. Pollen analytical dating: zone VIII (early) to IX (late) of the Scanian system (T. Nilsson, 1935). Subm. by Erik Mohrén, and Kaj Nilsson, Geol. Survey of Sweden, Stockholm.

\section{St-1212. Kistinge, M 124: 62}

$2110 \pm 90$

Humic sand layer below eolian sand at Kistinge, Snöstorp, Halland. Recent soil surface about +15 to $20 \mathrm{~m}$ alt on crest of cliff just above the postglacial marine beach at $+12 \mathrm{~m}$. The humic sand covers marine ferruginous sand and gravel, $0.8 \mathrm{~m}$ thick, resting upon weathered heavy glacial clay. Coll. and subm. by Erik Mohrén.

\section{St-1213. Påarp-Gullbranna M 77 : 62}

$1895 \pm 70$ A.D. 55

Sand from old soil surface under a cover of eolian sand. At Påarp, Trönninge, Halland (56 $35^{\prime} 56^{\prime \prime} \mathrm{N}$ Lat, $12^{\circ} 56^{\prime} 29^{\prime \prime}$ E Long). Stratigraphy from top: Eolian sand (soils surface about $+10 \mathrm{~m}$ alt); humic sand (old soil surface); postglacial coarse gravel (marine beach); glacial clay, weathered in reddish yellow colours. Coll. and subm. by Erik Mohrén.

\section{St-1232. S. Mellby M 33 : 62}

$5995 \pm 130$

4045 в.c.

Curve of Fagus pollen begins in this sample from Södra Mellby, Halland $\left(56^{\circ} 29^{\prime} 30^{\prime \prime} \mathrm{N}\right.$ Lat, $12^{\circ} 57^{\prime} 18^{\prime \prime}$ E Long). Coll. by Erik Mohrén.

\section{Falsterbo series}

In 1940, when digging the channel across the Falsterbo isthmus on the SW corner of Scania $\left(55^{\circ} 24^{\prime} 38^{\prime \prime} \mathrm{N}\right.$ Lat, $12^{\circ} 56^{\prime} 19^{\prime \prime}$ E Long; County: Malmöhus; Parish: Reng), the following section of the road bridge over the 
$\mathrm{N}$ end of the channel was found: soil surface $+3.5 \mathrm{~m}$ alt; +3.5 to $+2.7 \mathrm{~m}$, medium sand, in part eolian, in part marine; +2.7 to $-5.10 \mathrm{~m}$, fine sand, marine, with mollusc shells (Mytilus, Cardium, Hydrobia) ; -5.10 to $-5.40 \mathrm{~m}$, wood peat, telmatic-terrestrial, with Phragmites (top) and wood of Betula, Alnus, Quercus, Pinus and others (bottom), and hazelnuts (at other places, in the direction of the channel, probably at the bottom of this stratum, were found antlers and bones of reindeer) ; -5.40 to $-5.80 \mathrm{~m}$, fine sand, calcareous, nonfossiliferous, presumably late-glacial; -5.80 to $-6.50 \mathrm{~m}$, sand with pebbles of flint and Danian limestone (Late-glacial) ; -6.50 to $-7.0 \mathrm{~m}$, boulder and pebble layer; -7.0 to $-10.6 \mathrm{~m}$, boulder clay.

As the contact between the peat and the marine mud (gyttja) is very distinct, this series is very valuable for dating of the Littorina transgression.

\section{St-1233. Falsterboleden 1}

Telmatic-terrestrial wood peat with Phragmites rhizomes.

\section{St-1215. Falsterboleden 13}

Wood peat, muddy, in contact (top) with marine mud.

\section{St-1216. Falsterboleden 26}

Wood peat with wood of birch and alder. Coll. by Nils Nilsson Linner. mark, Malmö; subm. by Erik Mohrén.

\section{Eolian and pollen series}

Various kinds of peat from different peat-bogs in Sweden. Investigation was made in order to date pollen levels and levels with eolian material. Coll. and subm. by Christer Persson, Dept. of Quaternary Research, Univ. of Stockholm.

\section{St-1424. Ãnn C 16 \\ $\left(62^{\circ} 18^{\prime} \mathrm{N}\right.$ Lat, $12^{\circ} 28^{\prime} \mathrm{E}$ Long $)$. \\ St-1425. Ānn C 17 \\ St-1461. Sundbornsmossen \\ (60 $30^{\circ}$ N Lat, $15^{\circ} 38^{\prime}$ E Long).}

\section{St-1462. Grövelsjömyren}

( $62^{\circ} 05^{\prime} \mathrm{N}$ Lat, $12^{\circ} 25^{\prime} \mathrm{E}$ Long)

St-1488. Mellstabromossen 76-78

$\left(60^{\circ} 30^{\prime} \mathrm{N}\right.$ Lat, $15^{\circ} 22^{\prime}$ E Long)

St-1493. Mellstabromossen 122-124

St-1520. Mellstabromossen 46-48
$7730 \pm 100$ 5780 в.c. 5696 в.c.

$7545 \pm 100$ 5595 в.c.
$7645 \pm 110$

$830 \pm 70$ A.D. 1120

$3585 \pm 80$ 1635 в.C.

$2775 \pm 70$ 825 в.C.

$1045 \pm 70$ A.D. 945

$1875 \pm 70$ A.D. 75

$2855 \pm 80$

935 в.c.

$1220 \pm 70$ A.D. 730 
St-1455. Klaxsjömossen 1

( $59^{\circ} 30^{\prime} \mathrm{N}$ Lat, $13^{\circ} 06^{\prime} \mathrm{E}$ Long)

\section{St-1456. Klaxsjömossen 2}

$2810 \pm 75$

860 в.с.

St-1518. Klaxsjömossen 196-198

$3475 \pm 80$

1525 в.C.

St-1519. Klaxsjömossen 176-178

\section{Undersåker series}

Three samples of peat, covered by a layer of silt or moraine-like material. Two are from Ottsjö (63 $13^{\circ} \mathrm{N}$ Lat, $13^{\circ} 31^{\prime} \mathrm{E}$ Long), Undersåker, Jämtland. One is from Fångåmon $\left(63^{\circ} 11^{\prime} \mathrm{N}\right.$ Lat, $13^{\circ} 09^{\prime} \mathrm{E}$ Long $)$. Coll. and subm. by Karin Klein, Dept. of Quaternary Research, Univ. of Stockholm.

\section{St-1449. Ottsjö 1}

St-1486. Ottsjö 2

\section{St-1487. Fångåmon}

Two samples of lacustrine mud from lakes in Jämtland: Lake Hottöjen $\left(63^{\circ} 12^{\prime} \mathrm{N}\right.$ Lat, $13^{\circ} 51^{\prime} \mathrm{E}$ Long $)$, and Lake Gesten $\left(63^{\circ} 12^{\prime} \mathrm{N}\right.$ Lat, $13^{\circ} 30^{\prime} \mathrm{E}$ Long), Undersåker, Jämtland. Coll. and subm. by Karin Klein.

\section{St-1453. Hottöjen 1 B}

$9255 \pm 185$ 7305 в.с.

\section{St-1470. Gesten $1: 11$}

\section{Stockholm shore-displacement series}

$10,640 \pm 170$ 8690 в.C.

Algal gyttja taken where diatoms indicate a change from slightly brackish to fresh water, supposedly marking isolating level, in various localities in the Stockholm district. Coll. and subm. by Erik Åse, Dept. of Geog., Univ. of Stockholm.

\section{St-1475. Näcksjön 1}

$$
\begin{array}{r}
670 \pm 90 \\
\text { A.D. } 1280
\end{array}
$$

Algal gyttja (core 1) taken 150 to $152 \mathrm{~cm}$ below sealevel in NW part of Lake Näcksjön ( $59^{\circ} 21^{\prime}$ N Lat, $18^{\circ} 17^{\prime}$ E Long), Kummelnäs, province Stockholm.

\section{St-1255. Bodaträsk 1}

$$
1380 \pm 70
$$$$
\text { A.D. } 570
$$

Algal gyttja from 122.5 to $125 \mathrm{~cm}$ below land surface at present shore of $\mathrm{SW}$ part of Lake Bodaträsk, province Stockholm $\left(59^{\circ} 26^{\prime} \mathrm{N}\right.$ Lat, $18^{\circ} 16^{\prime} \mathrm{E}$ Long).

St-1119. Roslags Näsby 23 - 25

$$
2160 \pm 80
$$$$
210 \text { в.C. }
$$

Algal gyttja 23 to $25 \mathrm{~cm}$ below present land surface $400 \mathrm{~m}$ SSW of 
Roslags Näsby railway station, Täby, Stockholm $\left(59^{\circ} 26^{\prime} \mathrm{N}\right.$ Lat, $18^{\circ} 03.5^{\prime} \mathrm{E}$ Long).

St-1 184. Våtängsträsk 1 : 83 - 85

$2660 \pm 110$ 710 в.с.

Algal gyttja from 83 to $85 \mathrm{~cm}$ below land surface at present shore of $\mathrm{W}$ part of Lake Våtängsträsk, Ingarö, province Stockholm $\left(59^{\circ} 18^{\prime} \mathrm{N}\right.$ Lat, $18^{\circ} 22^{\prime}$ E Long).

\section{St-1279. Väsjön II}

$3995 \pm 120$

2045 в.c.

Algal gyttja taken 182to $185 \mathrm{~cm}$ below land surface at present shore of $\mathrm{NW}$ part of Lake Väsjön, province Stockholm $\left(59^{\circ} 28^{\prime} \mathrm{N}\right.$ Lat, $17^{\circ} 59^{\prime} \mathrm{E}$ Long).

\section{Skedemosse series}

Geological field work was carried out together with archaeological excavations to investigate the natural history of the Skedemosse as to changes of water level of the ancient lake, the formation of fen communities, and the vegetational history of the vicinity. The older parts of the sequences are connected with the Ancylus transgression of the Baltic area. From 7700 B.P. and upwards datings belong to limnic and fen stages of the basin.

Extensive pollen analytical works are to be carried out and the first part will be published in the fall of 1965. A report will be given at the INQUA Congress in Denver, Col., in Sept. 1965. Submitter of the geological samples is L. K. Königsson, Geol. Survey of Sweden.

St-1068. Skedemosse 8 - G

$9255 \pm 115$

Piece of wood $69 \mathrm{~cm}$ below surface.

St-1091. Skedemosse 13/15 G

Piece of wood below the "Ancylus wall."

St-1094. Skedemosse 7/9 - G

Wood in sandy gyttja ca. $5 \mathrm{~m}$ below surface.

St-1096. Skedemosse 4 - G

Piece of wood $26 \mathrm{~cm}$ below surface.

St-1097. Skedemosse Ad 2 - G

Piece of wood $55 \mathrm{~cm}$ below surface.

St-1296. Skedemosse 10 G

Piece of wood 30 to $35 \mathrm{~cm}$ below surface.

St-1297. Skedemosse 13 G

Peat $23 \mathrm{~cm}$ below surface.

$9180 \pm 160$

7330 в.c.

$$
1110 \pm 80
$$

$2570 \pm 100$

620 в.c.

$7065 \pm 155$

5115 в.c.

$$
2395 \pm 85
$$

445 в.C.

$3775 \pm 95$

1825 в.C. 


\section{St-1298. Skedemosse 14 G}

Peat $25 \mathrm{~cm}$ below surface.

\section{St-1299. Skedemosse 15 G}

Wooden stick $54 \mathrm{~cm}$ below surface.

\section{St-1300. Skedemosse 20 G}

Peat $28 \mathrm{~cm}$ below surface.

St-1301. Skedemosse 21 G

Peat $30 \mathrm{~cm}$ below surface.

\section{St-1349. Skedemosse 513 G}

Piece of wood in calcareous mud.
$4075 \pm 85$

2125 B.C.

$8430 \pm 210$

6480 в.C.

$3880 \pm 75$

1930 B.C.

$4310 \pm 75$

2360 в.C.

$8785 \pm 110$

6835 B.C.

\section{Huskvarna series I}

Wood and peat samples from Huskvarnaviken $\left(57^{\circ} 47^{\prime} \mathrm{N}\right.$ Lat, $14^{\circ} 15^{\prime} 5^{\prime \prime}$ E Long), Huskvarna, Småland. Subm. by H. Bergenblad, Town Mus. of Huskvarna.

\section{St-1525. Huskvarnaviken A peat}

$2460 \pm 70$

Peat around a pole (pole is sample St-1526).

\section{St-1526. Huskvarnaviken A wood} sealevel.

Pole $3.75 \mathrm{~m}$ below surface of Lake Vättern, which is situated $88.5 \mathrm{~m}$ above

\section{St-1527. Huskvarnaviken D}

$1000 \pm 70$

Pole of oak. May be remains of a harbor, now submerged.

\section{Huskvarna series II}

Because of unequal land uplift there has been since ca. 7650 в.c. a continuous and still noticeable submergence in southern parts of Lake Vättern, Sweden. Peat and stumps of Scotch pine have been found along a submerged bar which transverses the Huskvarna bay at southern end of the lake $\left(57^{\circ} 48^{\prime}\right.$ N Lat, 14 ${ }^{\circ} 15^{\prime}$ E Long). Subm. by J. O. Norrman, Dept. of Geography, Univ. of Uppsala.

\section{St-1056. Huskvarna T 1}

$2840 \pm 90$

890 B.C.

Sample from stump of Scotch pine. Depth of $4 \mathrm{~m}$ below present lake level. Coll. by J. O. Norrman.

\section{St-1057. Huskvarna M 521}

$$
590 \pm 65
$$

$$
\text { A.D. } 1360
$$

Peat from a fen situated inside submerged bar. Peat, ca. $1 \mathrm{~m}$ thick, is rich in Carex and Equisetum and reaches up to $0.85 \mathrm{~m}$ below present lake level. Taken 4 to $8 \mathrm{~cm}$ below peat surface. Coll. by J. O. Norrman, Dept. of Geography, and L. K. Königsson, Dept. of Quaternary Geol., Univ. of Uppsala. 
St-1058. Huskvarna M 534

Same place as St-1057, 60 to $64 \mathrm{~cm}$ below peat surface.

\section{B. Other Countries}

\section{St-1106. Buchanan, Liberia}

$9485 \pm 110$

Wood from layer of tree stumps standing on root 12 to $13 \mathrm{~cm}$ below mean low water and covered with sand and clay at Buchanan $\left(5^{\circ} 52^{\prime} 12^{\prime \prime} \mathrm{N}\right.$ Lat, $10^{\circ} 3^{\prime} 49^{\prime \prime} \mathrm{E}$ Long), Liberia. Date gives a maximum value of the corresponding level of the sea. Coll. and subm. by SENTAB, Stockholm.

\section{St-1087. Island 1}

$$
6890 \pm 90
$$

4940 в.c.

Birch-wood in peat (being pollen-analyzed by Palynological Lab., Solna, and Björn Berglund, Univ. of Lund) from Hörnjafjördur, SE Iceland (64 $17^{\prime}$ $\mathrm{N}$ Lat, $15^{\circ} 7^{\prime} \mathrm{E}$ Long). Found $290 \mathrm{~cm}$ below surface in soil surface less than $10 \mathrm{~m}$ above sea. Layer is older than first settlement on Iceland, in 9th Century. An exact date, combined with pollen-analysis, may provide a list of plants that were present on the island before man arrived and thus materially contribute to solve the question of how much the present flora (and fauna) of the North Atlantic islands has been modified by human dispersal. Subm. by Carl H. Lindroth, Zool. Inst., Univ. of Lund.

\section{ARCHAEOLOGIC SAMPLES}

\section{Västerljung series}

\section{A. Sweden}

Samples from a habitation site, under a Viking Age grave field, Tuna ( $58^{\circ} 54^{\prime} \mathrm{N}$ Lat, $17^{\circ} 28^{\prime} \mathrm{E}$ Long), Västerljung parish, Södermanland. Site was sandy slope of a ridge, about $23 \mathrm{~m}$ above sealevel. Habitation layer found 0.2 to $0.5 \mathrm{~m}$ below the turf and was about 0.1 to $0.4 \mathrm{~m}$ deep. It was partly covered with layer graves with a layer of sand between, about $0.2 \mathrm{~m}$ deep. Graves were covered with mounds of sand, 0.1 to $1 \mathrm{~m}$ high. Coll. and subm. by Bo Gräslund, Royal Office of Antiquities, Stockholm.

St-1386. Västerljung A 26 : F 162

Charcoal from hearth.

\section{St-1387. Västerljung F 132}

Charcoal from culture layer.

\section{St-1388. Västerljung F 136}

Charcoal from culture layer.

\section{St-1389. Västerljung F 137}

Scrapings from the inside of pottery.
$1515 \pm 80$ A.D. 435

$2605 \pm 80$ 655 B.C.

$2550 \pm 70$ 600 в.C.

$2475 \pm 80$ 525 в.C. 


\section{St-1390. Västerljung F 160}

"Dark earth": charcoal blended with soil.

St-1391. Västerljung A 23 : F 48

Charcoal from hearth.

$$
2330 \pm 100
$$

380 в.c.

$1545 \pm 100$ A.D. 405

\section{Ösmo series}

Gravefield on gravel ridge near Älby farm, Ösmo $\left(58^{\circ} 57^{\prime} \mathrm{N} \mathrm{Lat}, 17^{\circ} 54^{\prime}\right.$ E Long), Södermanland. Samples of charcoal, no stratification. Coll. by Birgitta von Heland, Mus. of Natl. Antiquities, Stockholm; subm. by Mats Malmer.

St-1034. Ösmo A 2

St-1035. Ösmo A 6

St-1036. Ösmo A 14

St-1037. Ösmo A 89

St-1040. Ösmo A 505

St-1041. Ösmo A 511

St-1042. Ösmo A 530

St-1043. Ösmo A 536

St-1044. Ösmo A 555 : 3

St-1045. Ösmo A 565

St-1046. Ösmo A 568
St-1038. Ösmo A 103

$$
\begin{aligned}
& 1565 \pm 80 \\
& \text { A.D. } 385 \\
& 1460 \pm 70 \\
& \text { A.D. } 490 \\
& 1500 \pm 65 \\
& \text { A.D. } 450 \\
& 785 \pm 65 \\
& \text { A.D. } 1165 \\
& 1440 \pm 65 \\
& \text { A.D. } 510 \\
& \text { A.D. } 500 \\
& 1440 \pm 65 \\
& \text { A.D. } 510 \\
& 1915 \pm 65 \\
& \text { A.D. } 35 \\
& 1575 \pm 65 \\
& \text { A.D. } 375 \\
& 1725 \pm 65 \\
& \text { A.D. } 225 \\
& 1815 \pm 65 \\
& \text { A.D. } 135 \\
& 1430 \pm 65 \\
& \text { A.D. } 520
\end{aligned}
$$

\section{Resin caulking series}

Resin has been found useful for $\mathrm{C}^{14}$ dating. Resin caulking is often found in Swedish graves from early Iron Age (500 B.c. to A.D. 500). Radiocarbon dating has given the same result as archaeological dating, but in some cases when more than one method is applicable, the $\mathrm{C}^{14}$ dates have proved about one 
or two centuries older. The following samples are made as a control series on gravefinds with both resin caulking and artifacts which can be archaeologically dated, and document this difference; a fuller account will be published by Björn Ambrosiani and Birgit Arrhenius. Subm. by B. Ambrosiani, Royal Office of Antiquities and B. Arrhenius, Mus. of Natl. Antiquities, Stockholm.

\section{St-1311. Drottningbacken A 11}

From Lunda $\left(59^{\circ} 40^{\prime} \mathrm{N}\right.$ Lat, $17^{\circ} 58^{\prime} \mathrm{E}$ Long), Uppland.

St-1313. Husby-Ärlinghundra A 4 - F 15

$2460 \pm 70$

520 в.c.

From Husby Ärlinghundra (59 $38^{\prime} \mathrm{N}$ Lat, $17^{\circ} 50^{\prime}$ E Long), Uppland.

St-1314. Järfälla $40 \mathrm{~V}$

From Järfälla ( $59^{\circ} 24^{\prime} \mathrm{N}$ Lat, $17^{\circ} 52^{\prime} \mathrm{E}$ Long $)$, Uppland.

St-1315. Helgö 43

St-1316. Helgö 46

From Ekerö ( $59^{\circ} 16^{\prime} \mathrm{N}$ Lat, $17^{\circ} 43^{\prime}$ E Long), Uppland.

St-1317. Älby 49

St-1318. Älby 52

From Ösmo parish ( $58^{\circ} 57^{\prime}$ N Lat, $17^{\circ} 54^{\prime}$ E Long), Södermanland.

St-1426. Unsarve 10324 : 16

St-1427. Unsarve $10438: 18$

From Halla parish $\left(57^{\circ} 32^{\prime} \mathrm{N}\right.$ Lat, $18^{\circ} 30^{\prime} \mathrm{E}$ Long $)$, Gotland.

St-1428. Unsarve $10438: 30$

St-1429. Nyckelby $20418: 3$

From Ekerö parish (59 $16^{\prime} \mathrm{N}$ Lat, $17^{\circ} 43^{\prime}$ E Long), Uppland.

$$
\begin{gathered}
2140 \pm 80 \\
190 \text { в.C. }
\end{gathered}
$$

$1995 \pm 110$

45 в.c.

$1965 \pm 75$

15 B.c.

$1965 \pm 80$

15 B.c.

St-1430. Ängeby 23794: 6

From Lunda parish $\left(59^{\circ} 40^{\prime} \mathrm{N}\right.$ Lat, $18^{\circ} 3^{\prime} \mathrm{E}$ Long), Uppland.

St-1431. Igelbäcken $26024: 46$

$2320 \pm 80$

370 в.с.

From Järfälla parish $\left(59^{\circ} 26^{\prime} \mathrm{N}\right.$ Lat, $17^{\circ} 52^{\prime} \mathrm{E}$ Long $)$, Uppland. 
St-1432. Norrbacka 19915 : 1

St-1433. Norrbacka $19915: 4$

St-1434. Norrbacka 19915 : 10 A

From Solna ( $59^{\circ} 21^{\prime} \mathrm{N}$ Lat, $18^{\circ} 2^{\prime}$ E Long), Uppland.

St-1435. Rangsarve $9121: 5$

St-1436. Rangsarve $9121: 12$

St-1437. Rangsarve $9121: 13$

St-1438. Rangsarve $9121: 14$

From Alva ( $57^{\circ} 12^{\prime} \mathrm{N}$ Lat, $18^{\circ} 20^{\prime}$ E Long), Gotland.
$1625 \pm 70$

A.D. 325

$$
1490 \pm 70
$$$$
\text { A.D. } 460
$$

$1625 \pm 75$

A.D. 325

$$
\begin{array}{r}
2080 \pm 75 \\
130 \text { B.C. } \\
1855 \pm 70 \\
\text { A.d. } 95 \\
1905 \pm 70 \\
\text { A.d. } 45 \\
1825 \pm 100 \\
\text { A.D. } 125
\end{array}
$$

\section{Darsgärde series}

Samples from culture layers and grave-fields from early Iron Age at Darsgärde, Skederid parish, Uppland $\left(59^{\circ} 43^{\prime} \mathrm{N}\right.$ Lat, $18^{\circ} 30^{\prime}$ E Long). For earlier samples from the hillfort at the same place, see St-886 to 896, 1017, 1019 (Stockholm V). Part of the series also belongs to the resin caulking series. An account is given by Ambrosiani (1964). Subm. by Björn Ambrosiani.

St-1069. Dg : N 210:F 254

Resin caulking.

St-1070. Dg : S 16:F 35

Charcoal.

St-1071. Dg : N 303:F 313

Resin caulking.

St-1072. Dg : N 213:F 241

Resin caulking.

St-1073. Dg : N 143:F 105

Resin caulking.

St-1074. Dg : S 66:F 94

St-1075. Dg : N 203:F 228

Resin caulking.
$1805 \pm 80$ A.D. 145

$345 \pm 75$

A.D. 1605

$$
\begin{aligned}
& 2195 \\
& 245 \text { B.C. }
\end{aligned}
$$

$1955 \pm 80$

5 в.c.

$1885 \pm 80$

A.D. 65

$2110 \pm 80$

160 в.c.

$1955 \pm 65$

5 в.c. 
St-1076. Dg : S 54:F 107

$2150 \pm 80$

Resin caulking.

St-1077. Dg : S 68:F 123

200 B.C.

Resin caulking.

St-1078. Dg : S 55:F 85

$2025 \pm 65$

75 B.c.

Resin caulking.

St-1079. Dg : S 70:F 126

$2070 \pm 65$

120 B.C.

St-1080. Dg : N IV-VI:F 73

$2130 \pm 65$

180 B.c.

$2130 \pm 65$

180 в.C.

St-1081. Dg : N 230:N 22

$2150 \pm 70$

Charcoal.

St-1082. Dg : S 34:F 63

$2120 \pm 80$

Resin caulking.

St-1083. Dg : N 126

$2070 \pm 75$

120 в.c.

Charcoal.

St-1084. Dg : S 35:F 49

$1985 \pm 80$

35 в.c.

St-1085. Dg : S 58:F 120

$2080 \pm 100$

130 в.c.

\section{Dragby series}

Samples from large prehistoric cemetery at Dragby $\left(59^{\circ} 59^{\prime} \mathrm{N}\right.$ Lat, $17^{\circ}$ $35^{\prime}$ E Long), Skuttunge parish, Uppland. The field includes ca. 330 visible constructions belonging to one continuous series, or possibly two periods, from Late Neolithic to early Roman Iron Age. Coll. 1961 by Stig Ryd; subm. by M. Stenberger, Inst. of Scandinavian Archaeol., Univ. of Uppsala. Other samples have been dated by Olsson (Uppsala I and II) and in Stockholm IV. Site is described by Stenberger (1960) and others.

St-1439. Dragby 42

$1625 \pm 115$

Charcoal.

St-1441. Dragby 56 A.D. 325

Charcoal.

$$
\begin{gathered}
2080 \pm 80 \\
130 \text { в.с. }
\end{gathered}
$$

St-1442. Dragby 146

$2245 \pm 80$

Charcoal.

295 в.C. 
St-1443. Dragby 194

Charcoal.

St-1444. Dragby 360

Dark humus.

St-1445. Dragby 371

Charcoal.

St-1446. Dragby Uo X, 65G, G2

Charcoal.

St-1447. Dragby Uo X, 65G, G4

Charcoal.

$$
575 \pm 75
$$

A.D. 1575

$1470 \pm 60$ A.D. 480

$2730 \pm 80$

780 в.C.

$2820 \pm 60$

870 в.C.

\section{Såntorp series}

Samples from gravefield at Såtorp $\left(58^{\circ} 25^{\prime} \mathrm{N}\right.$ Lat, $13^{\circ} 40^{\prime} \mathrm{E}$ Long $)$, Eggby parish, Västergötland. Gravefield consists of two strata, one older with hitherto about 240 urnpits from early Iron Age (100 B.c. to A.D. 200) under thin soil, and one younger with cremation layers from late Iron Age (A.D. 600 to 1000). Coll. by Inga Lundström, Royal Office of Antiquities, Stockholm; subm. by Ulf-Erik Hagberg.

St-1393. Eggby A 1

Charcoal.

St-1394. Eggby A 9

Charcoal.

St-1396. Eggby A 23

Resin caulking.

St-1397. Eggby A 30

Resin caulking.

St-1398. Egghy A 48

Charcoal.

St-1399. Eggby A 51

Resin caulking.

St-1400. Eggby A 53

Resin caulking.

St-1401. Eggby A 58

Charcoal and resin caulking.
$1260 \pm 70$ A.D. 690

$$
\begin{gathered}
2050 \pm 75 \\
100 \text { в.с. } \\
2195 \pm 75 \\
245 \text { в.c. } \\
2145 \pm 75 \\
195 \text { в.c. } \\
2030 \pm 65 \\
80 \text { в.с. } \\
2250 \pm 60 \\
300 \text { в.с. } \\
2110 \pm 70 \\
160 \text { в.с. } \\
2160 \pm 70 \\
210 \text { в.c. }
\end{gathered}
$$


St-1402. Eggby A 61

Resin caulking.

\section{St-1403. Eggby A 131}

Charcoal.

$$
\begin{aligned}
2070 & \pm 70 \\
120 & \text { в.c. } \\
1790 & \pm 95 \\
\text { A.d. } 160 &
\end{aligned}
$$

\section{Klagstorp series}

Samples of charcoal from graves and ancient arable land at Klagstorp ( $58^{\circ} 20^{\prime} \mathrm{N}$ Lat, $13^{\circ} 52^{\prime} \mathrm{E}$ Long), N. Kyrketorp parish, Västergötland. Investi-

\begin{tabular}{|c|c|c|}
\hline St-1281. & Klagstorp A 1 & $\begin{array}{r}355 \\
\text { A.D. } 1595\end{array}$ \\
\hline St-1282. & Klagstorp A 2 & $\begin{array}{r}360 \pm 70 \\
\text { A.D. } 1590\end{array}$ \\
\hline St-1283. & Klagstorp A 3 & $<\mathbf{2 5 0}$ \\
\hline St-1303. & Klagstorp A $3: 2$ & $\begin{aligned} 760 & \pm 70 \\
\text { A.D. } 1190 & \end{aligned}$ \\
\hline St-1284. & Klagstorp $\ddot{0} 1$ & $<\mathbf{2 5 0}$ \\
\hline St-1302. & Klagstorp Str 17 & $\begin{aligned} 310 & \pm 75 \\
\text { A.D. } 1640 & \end{aligned}$ \\
\hline St-1285. & Klagstorp Str 26 & $\begin{array}{r}610 \\
\text { A.D. } 1340\end{array}$ \\
\hline St-1286. & Klagstorp Str 41 & $\begin{array}{l}345 \\
\text { A.D. } 1605\end{array}$ \\
\hline St-1287. & Klagstorp Str 42 & $\begin{aligned} \mathbf{5 4 0} & \pm \mathbf{7 0} \\
\text { A.D. } 1410 & \end{aligned}$ \\
\hline St-1358. & Klagstorp Str $26:$ A 4 & $\begin{array}{r}465 \\
\text { A.D. } 1485\end{array}$ \\
\hline \multicolumn{3}{|c|}{$\begin{array}{l}\text { Charcoal from gravefield at Sköllunga }\left(58^{\circ} 6^{\prime} \mathrm{N} \text { Lat, } 10^{\circ} 58^{\prime} \text { E Long), }\right. \\
\text { dum parish, Bohuslän. Coll. by Hille Jaanusson, Royal Office of Antiquities, } \\
\text { ckholm; subm. by U.-E. Hagberg. }\end{array}$} \\
\hline St-1271. & Sköllunga A 81 : 106 & $\begin{aligned} 2375 & \pm 80 \\
425 & \text { в.c. }\end{aligned}$ \\
\hline St-1272. & Sköllunga A 82 : 101 & $\begin{array}{c}2430 \pm 110 \\
480 \text { в.с. }\end{array}$ \\
\hline
\end{tabular}
gation was made in order to reveal different ages of the gravefields and the ancient arable land. Coll. by Jutta Valler and Hugo Svensson, Royal Office of Antiquities; subm. by U.-E. Hagberg.

Samples of charcoal of alder from burials under central slabs in a pair of circles of big stone. Both samples are exceptionally early. Stone circles in Sweden are usually dated 4th to 6th Century A.D. 
St-1273. Sköllunga A $507: 115$

Charcoal of alder and pine from hearth in a third circle of stones. No traces of a burial.

\section{Keddek series}

Samples from a site on $\mathrm{E}$ cave on $\mathrm{N}$ side of the sea, at Lake Keddek, Blackälven, Jokkmokk parish, Lappland $\left(67^{\circ} 04^{\prime} \mathrm{N}\right.$ Lat, $18^{\circ} 17^{\prime} \mathrm{E}$ Long $)$. Behind the sandy beach ca. $2 \mathrm{~m}$ broad is a small plain area where most of the finds, mainly scrapers and fragmentary spear-and arrowheads of quartzite were found, 6 to $30 \mathrm{~cm}$ under the peat. Coll. 1961 by Göran Rosander, Royal Office of Antiquities, Stockholm; subm. by Harald Hvarfner.

\section{St-1051. Keddek 1}

Charcoal layer ca. $1 \mathrm{~cm}$ thick covering a circular hearth stone, $10 \mathrm{~cm}$ under the peat.

\section{St-1052. Keddek 2}

Humus soil from culture stratum on the same layer as St-1051, but $5 \mathrm{~m}$ from that point.

\section{Krankmårtenhögen series}

Gravefield at Krankmårtenhögen in Storsjö parish $\left(62^{\circ} 46^{\prime} 40^{\prime \prime} \mathrm{N}\right.$ Lat. $13^{\circ} 13^{\prime} 23^{\prime \prime}$ E Long), Härjedalen. Gravefield consists of ca. 20 triangular stone-settings with erected stone-slabs at the corners. On surface of stonepavements lies much elk and reindeer antler and bone. Gravefield is second one from early Iron Age in these inner parts of the Swedish mainland. See also Lossnen series (St 511-12, Stockholm IV). Coll. by Göran Stolpe, Royal Office of Antiquities, Stockholm; subm. by Margareta Biörnstad.

\section{St-1381. Krankmårtenhögen 1}

Charcoal.

\section{St-1382. Krankmårtenhögen 2}

Charcoal blended with soil.

\section{St-1383. Krankmårtenhögen 3}

Charcoal.

\section{St-1384. Krankmårtenhögen 4}

Resin caulking.

\section{St-1524. Vä kyrka}

$$
2290 \pm 70
$$

340 в.c.

$$
2730 \pm 90
$$

780 в.с.

$$
\begin{aligned}
& 5085 \pm 160 \\
& 3135 \text { в.C. }
\end{aligned}
$$

$$
1915 \pm 120
$$$$
\text { A.D. } 35
$$

$$
1335 \pm 85
$$$$
\text { A.D. } 615
$$

Wood from a $7 \mathrm{~m}$ long beam bricked into $\mathrm{E}$ wall of the nave in Vä church $\left(56^{\circ} \mathrm{N}\right.$ Lat, $14^{\circ} \mathrm{E}$ Long), Skåne, $\mathrm{N}$ of the triumphal arch on same level as its vault support. Beam has been placed during erection of the wall, and should date it. For art-history reasons Vä church is considered to have been built in 
the middle of the 12th century. Subm. by Erik Bohrn, Royal Office of Antiquities, Stockholm. Comment (E.B.). result is puzzling. Perhaps the wood was an old $\log$, or was cut from the old heart of a large tree, or both.

St-1251. Akermyren

$7835 \pm 180$

5885 в.c.

Charcoal taken from a partly charred piece of wood, found close to the finding place for a paddle at depth of $2.5 \mathrm{~m}$, in the bog Åkermyren, Västerby, Hedemora. Dalarna $\left(60^{\circ} 17^{\prime} \mathrm{N}\right.$ Lat, $16^{\circ} \mathrm{E}$ Long). Coll. and subm. by Louise Cederschiöld, Mus. of Natl. Antiquities, Stockholm.

\section{St-1139. Igelsta 9 B}

$$
2980 \pm 70
$$

Charcoal from cairn of brittle-burned stones at Igelsta Farm, Östertälje $\left(59^{\circ} 11^{\prime} \mathrm{N}\right.$ Lat, $17^{\circ} 40^{\prime} \mathrm{E}$ Long). Coll. 1958 by Birgitta von Heland (cf. Stockholm IV, St-739); subm. by Mats Malmer.

\section{St-1342. Vålbergshögen F 49}

$$
1555 \pm 65
$$

Golden maidhair (moss) from a layer at depth of $2 \mathrm{~m}$ in a large barrow, not yet excavated, Nors parish, Värmland (59 $24^{\prime} \mathrm{N}$ Lat, $13^{\circ} 11^{\prime} \mathrm{E}$ Long). Subm. by Gunnar Ekelund, Royal Office of Antiquities, Stockholm.

\section{St-1295. Brännegården}

$1410 \pm 65$

Charcoal from hearth with flint artifacts, Brännegården, Böja parish ( $59^{\circ} \mathrm{N}$ Lat, $15^{\circ} \mathrm{E}$ Long). Subm. by Inga Lundström and U.E. Hagberg, Royal Office of Antiquities, Stockholm.

\section{St-1418. Selånger F 15, A 12}

Charcoal from grave $\mathrm{nr} 12$, gravefield $\mathrm{nr} 43$, Granlo $\left(63^{\circ} 24^{\prime} \mathrm{N}\right.$ Lat, $17^{\circ} 16^{\prime} 30^{\prime \prime} \mathrm{E}$ Long), Selånger parish, Västernorrland. Subm. by Margareta Biörnstad, Royal Office of Antiquities, Stockholm.

\section{Lillhärdal tub series}

Coopered tub with ornamented cover, NM 100.050 (NM means Nordiska Museet, Stockholm) from Lillhärdal parish (61 $51^{\prime} \mathrm{N}$ Lat, $14^{\circ} 01^{\prime} \mathrm{E}$ Long), Härjedalen. Subm. by Göran Bergengren, Nordiska Museet, Stockholm.

\section{St-1450. NM 100.050 : 1}

Piece of wood from the lower side of the cover.

St-1451. NM 100.050 : 2
$865 \pm 70$

A.D. 1085

A.D. 1060

Piece of wood from the lower side of the bottom of the tub.

\section{Malgomaj-Varris series}

Charcoal from asbestos ceramics found mostly on the sites 657 and 662 at the Lake Varris $\left(64^{\circ} 42^{\prime} \mathrm{N}\right.$ Lat, $16^{\circ} 24^{\prime} \mathrm{E}$ Long), S of Lake Malgomaj, $14 \mathrm{~km} \mathrm{NW}$ of Vilhelmina, Lappland, and also, for comparison, from site $\mathrm{T}$ 231 and $\mathrm{T} 231 \mathrm{~A}$, Lake Kultsjön $\left(64^{\circ} 58^{\prime} \mathrm{N}\right.$ Lat, $15^{\circ} 21^{\prime} \mathrm{E}$ Long), $75 \mathrm{~km} \mathrm{NW}$ 
of Vilhelmina, Lappland; site 792, Lake Lilla Laisan $\left(65^{\circ} 45^{\prime} \mathrm{N}\right.$ Lat, $15^{\circ} 10^{\prime} \mathrm{E}$

Long), $5 \mathrm{~km} \mathrm{NW}$ of Tärnaby, Lappland; and site T 227, Landverksströmmen, Lake Ånn $\left(63^{\circ} 19^{\prime} \mathrm{N}\right.$ Lat, $12^{\circ} 36^{\prime} \mathrm{E}$ Long $), 25 \mathrm{~km}$ SW of Äre, Jämtland. Charcoal from a pit of unknown function on site 662 was also dated; the pit contains fragmentary iron artifacts. The asbestos ceramics from the North of Sweden have been analyzed in conjunction with A. Linder's treatment of archaeological material from Malgomaj-Varris. The ceramics often contain a dark organic substance, so the $\mathrm{C}^{14}$ determinations can be made directly on the artifacts. No doubt the sites have been used during various periods, and asbestos pottery is believed to extend from the Bronze Age right into the Migration Period. The finds from Malgomaj-Variss were coll. 1956 and 1957 by Astrid Linder, Royal Office of National Antiquities; subm. by Mats Malmer, State Mus. of Natl. Antiquities, Stockholm.

St-1016. Site 662, Lappvallen no. 25

Charcoal from a pit.

St-1140. Site 657, Vallviksudden R-Y 137-139

Crushed sherds (8 $\mathrm{g}$ total weight).

St-1141. Site 657, Vallviksudden R-Y 137-139

Charcoal scraped from sherds $(5 \mathrm{~g})$.

St-1142. Site 662, Lappvallen V-X 86

Crushed sherds $(6 \mathrm{~g})$.

St-1143. Site 662, Lappvallen V-X 86

Charcoal scraped from sherds $(10 \mathrm{~g})$.

St-1350. Site 657, Vallviksudden $X$ 30-31

Crushed sherds $(15 \mathrm{~g})$.

St-1351. Site 657, Vallviksudden Y-Z 147

Crushed sherds $(15 \mathrm{~g})$.

St-1352. Site 662, Lappvallen V 85

Crushed sherds $(17 \mathrm{~g})$.

St-1353. Site 662, Lappvallen DD 82-83

Crushed sherds $(17 \mathrm{~g})$. St-1354. Site T 231, Kultsjön ("the Pot of
Kultsjön")

Crushed sherds $(17 \mathrm{~g})$.

St-1355. Site T 231 A, Kultsjön P 6

Crushed sherds $(17 \mathrm{~g})$.

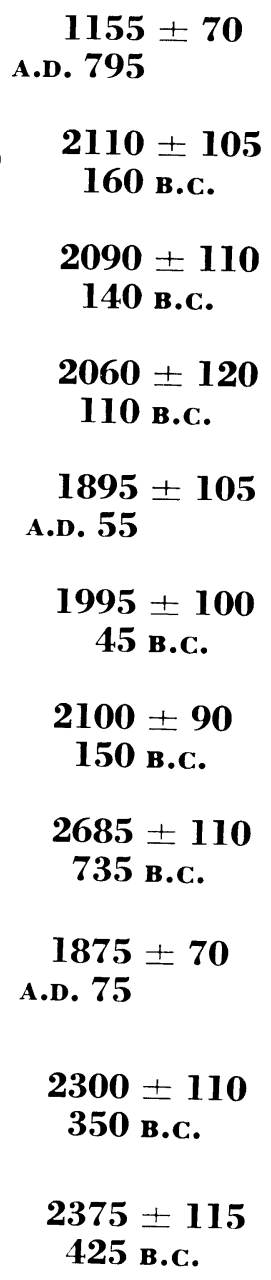


St-1356. Site 792, Lilla Laisan Z-CC 130-132 $\quad 3170 \pm 160$ ("the Pot of Laisan") 1220 B.C.

Crushed sherds (15 g).

\section{St-1357. Site T 227, Landverksströmmen Ānnsjön \\ $2020 \pm 110$ \\ 70 в.c.}

Crushed sherds (18 g).

\section{Skedemosse series, öland}

Samples from a drained fen, Skedemosse $\left(56^{\circ} 05^{\prime} \mathrm{N}\right.$ Lat, $16^{\circ} 45^{\prime} \mathrm{E}$ Long), Gärdslösa parish, öland, coll. from different layers and constructions in the fen. The normal profile has total depth of ca. $100 \mathrm{~cm}$ subdivided as follows: cultivated layer, peat, algal or fine-detritus gyttja, lime gyttja, sand, carr peat and moraine. In the upper gyttja were sacrificial finds consisting of partly destroyed jewelry, weapons, bones of animals and human beings, datable to the 4th and 5th Centuries A.D. It is comparable with well-known finds in Danish bogs, even surpassing them in its richness in gold. In the same layer were found floats and fish-hooks. Fishing activity is also shown by two fish weirs. The best-preserved one, from which samples St-618 and 619 (Stockholm IV) were collected, is of a type well-known from ethnographical material, but unknown in prehistoric contexts. The construction of these fish weirs precludes any dating other than by $\mathrm{C}^{14}$. A study concerning the drying up of the lake is being prepared by L. K. Königsson, Geol. Survey of Sweden. The strata are especially shallow in the western parts of the fen. See Hagberg (1964) with special attention to the discussion. Site is described by Hagberg (1963, 1964). Coll. 1959, 1960, 1962 and 1963 and subm. by U.E. Hagherg.

St-1095. Skedemosse F 119 $<200$

St-1098. Skedemosse F 118

$$
370 \pm 65
$$

\section{A.D. 1580}

Piece of wood from a juniper stake found horizontally between the ribs of a horse (Hagberg, 1961). No datable finds in the stratigraphic layers under or above the skeleton.

St-1348. Skedemosse 1008

$3460 \pm 105$

Bark float from northern part of the Skedemosse.

1510 в.C.

\section{St-1360. Skedemosse 1106}

$3485 \pm 85$

1435 в.C.

Wooden laths from a fish weir in southern part of Skedemosse.

\section{St-1361. Skedemosse $1106: 1$}

$3365 \pm 100$

Wooden pole which forms part of a fish weir.

\section{St-1362. Skedemosse 1124}

Charcoal from hearth on sandy ridge $W$ of Skedemosse. Some remains from iron smelting were found in this hearth. Flintscrapers and stone axes have been found in the surrounding fields. 
St-1363. Skedemosse 1125

Charcoal from a hearth (cf. St-1362).

\section{St-1359. Sörby tall F 21}

$2245 \pm 90$

295 B.c.

$$
1505 \pm 65
$$

A.D. 445

Charcoal from a posthole. An ornamented potsherd from the migration or vendal period was found in the same building. Settlement is situated $800 \mathrm{~m}$ SW of the fen Skedemosse. Research on this site, which is rather extensive, continues.

\section{Kumla series}

Charcoal from soil in Kumla region, Närke, dated as part of an investigation of prehistoric and medieval agriculture to establish possible earlier devastations of cultivated land. All samples are from charcoal horizons resulting from intentional clearing of land by fire. Coll. 1963 by Siv Augustson and Margareta Höglund, Dept. of Geography, Univ. of Stockholm; subm. by David Hannerberg, Dept. of Geography, Univ. of Stockholm.
St-1246. Brånsta 111
$645 \pm 100$
A.D. 1305

\section{St-1247. Brånsta 112}
$1665 \pm 100$

Charcoal from Kumla $\left(59^{\circ} 8^{\prime} \mathrm{N}\right.$ Lat, $15^{\circ} 7^{\prime} \mathrm{E}$ Long), Närke.

\section{St-1254. Vallerstahammaren 201}

St-1257. Vallerstahammaren 202

A.D. 1505

$$
445 \pm 70
$$

$1825 \pm 100$

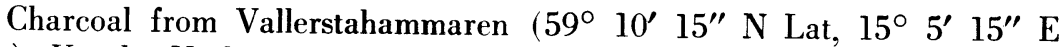
Long), Kumla, Närke.

\section{St-1259. Viaskogen 113}

A.D. 1395

St-1260. Viaskogen 114

$$
2495 \pm 100
$$

545 в.c.

Viaskogen $\left(59^{\circ} 6^{\prime} 20^{\prime \prime} \mathrm{N}\right.$ Lat, $15^{\circ} 8^{\prime} 45^{\prime \prime}$ E Long), Kumla, Närke.

\section{St-1261. Örstaskogen 117}

$1635 \pm 100$ Örstaskogen $\left(59^{\circ} 7^{\prime} \mathrm{N}\right.$ Lat, $15^{\circ} 7^{\prime} \mathrm{E}$ Long $)$, Kumla, Närke.

\section{St-1245. Hassla 128}

$455 \pm 70$

\section{A.D. 1495}

Charcoal from soil at Hassla, Vallerstad $\left(77^{\circ} \mathrm{N}\right.$ Lat, $15^{\circ} 6^{\prime} \mathrm{E}$ Long), Östergötland, was dated to establish possible earlier decastation of cultivated land. Sample is probably the remains of intentional clearing of land by fire. Coll. and subm. 1963 by Ulla Svennrud and Maud Steiner, Dept. of Geog., Univ. of Stockholm. 


\section{B. Other countries}

\section{Luni series}

From Luni, province Viterbo, Comune di Blera, Italy $\left(14^{\circ} 13^{\prime} \mathrm{N}\right.$ Lat, $11^{\circ} 56^{\prime}$ E Long). Subm. by C. E. Östenberg, Ist. Svedese, Rome, Italy. Swedish Institute in Rome, in collaboration with Soprintendenza per l'Etruria Meridionale (Villa Giulia), is excavating at two sites, San Giovenale and Luni, in S part of ancient Etruria. At Luni, discovered in 1960, there is a vast settlement from so-called Apennine Bronze Age, ca. 1400 to 900 B.c. Village consisted of real houses partly cut into tuff rock, and not of huts as is generally the case. According to one theory, Apennine Bronze Age culture was mainly pastoral with more or less nomadic shepherds. Our results suggest rather that they were well-settled farmers. Finds of pottery, stone, bone and bronze are numerous. The clear stratigraphy promises a reliable relative chronology, to be made absolute by Mycenaean sherds and especially by $\mathrm{C}^{14}$ dates. Finds of grain and seed and the great quantity of animal bones give a good idea of the ecological background.

\section{St-1144. Luni 1, Tr 1, Str 2}

$$
\begin{array}{r}
1075 \\
\text { A.D. } 875
\end{array}
$$

Acorn from hearth found in a rectangular house, the latest one of the prehistoric settlement.

\section{St-1147. Luni 1, Tre Erici, Saggio 1, Str 6 \\ $3075 \pm 70$ \\ 1125 в.c.}

Charcoal wood from E slope where a settlement from initial part of Iron Age was found.

\section{St-1340. Luni 4, Tre Erici, Tr 1, Str 3}

$2865 \pm 80$

915 в.c.

Charcoal from hearth in rectangular hut with wattle-and-daub walls on a stone foundation. A large quantity of Iron Age pottery (Tolfa Allumiere type) shows that this settlement belongs to the Iron Age.

\section{St-1341. Luni 5, Tre Erici, Tr 1, Str 6}

$2775 \pm 100$

825 B.c.

Charcoal from hearth in hut with floor of hard stamped clay with ashes, charcoal and animal bones. In this floor was found a burial of a young girl. Pottery found on this level suggests that the hut belongs to Late Apennine Bronze Age.

\section{St-1343. Luni 6, Tre Erici, Tr 1, Str 8}

$3800 \pm 80$

1850 в.C.

Charcoal from hearth in hut floor of irregular tuff stones covered with clay. On the floor were found animal bones, ashes, charcoal, and pottery. Pottery resembles Rinaldone cut ware from the Viterbo district, i.e. is Eneolithic and probably from ca. 2000 B.c.

\section{St-1344. Luni 7, Tre Erici, Tr 1, Str 10}

$5395 \pm 80$

3445 в.c.

Charcoal from hearth in hut with floor of hard stamped clay. Flint imple. ments (scrapers, etc.) and pottery fragments indicate late Neolithic. 


\section{St-1345. Luni 8, Apennine houses, Tr 16, B, Str $43195 \pm 75$

The Apennine Bronze Age settlement at Luni consists of long houses, partly cut into the tuff bedrock. Three houses placed across the plateau formed a wall that also served as a defence. Southern house is $42 \mathrm{~m}$ long and $4.5 \mathrm{~m}$ wide. Three different habitation periods, corresponding to the Strata 5, 4, and 3 have been observed. Mycenaean sherds found in this context indicate that houses were built ca. 1400 B.c. and were in use for ca. $400 \mathrm{yr}$, but datable material was scarce and only $\mathrm{Str} 4$ could be dated by $\mathrm{C}^{14}$.

\section{St-1346. Luni 9, Str 9}

$2785 \pm 70$

835 B.c.

Wood from burned roof of a building of monumental dimensions at $\mathbb{W}$ point of Luni plateau. Building measures ca. $19 \times 10 \mathrm{~m}$ and has been cut down to ca. $6 \mathrm{~m}$ into bedrock. Once roofed with wood, it was plundered and destroyed. Stratum 8, the bottom layer, is a sealed deposit, containing pottery and objects which were in the house when the wooden roof fell.

St-1339. Morgantina 1, Area III, Tr 29, Str 6 B

$2695 \pm 70$

745 B.C.

Charred wood from wooden posts of oval huts, found in situ in postholes cut in bedrock, province Enna, Comune di Aidone, Cittadella (37 $26^{\prime} 20^{\prime \prime} \mathrm{N}$ Lat, $14^{\circ} 30^{\prime}$ E Long). Subm. by C. E. Östenberg, Morgantina (in Sicily), like a site on the island of Lipari, is a manifestation of Ausonian culture, now recognized as a phase of the widespread Apennine Bronze Age, and belongs to its later part, ca. $1200-900$ B.C.

\section{Palaikastro series}

Charcoal from excavations in Siteia district $\left(35^{\circ} \mathrm{N}\right.$ Lat, $26^{\circ} \mathrm{E}$ Long), Crete, Greece, carried out by British School of Archaeol. at Athens under direction of Hugo Sakett and M. R. Popham. Coll. by M. R. Popham, British School of Archaeol.; subm. by Paul Åström, Univ. of Lund.

\section{St-1263. Palaikastro 1}

Found in pithos in house of Late Minoan date, destroyed in Late Minoan I b (PK 63, BB 11, East, Balk, level 2).

\section{St-1264. Palaikastro 2}

$3510 \pm 120$

1560 в.c.

Remains of threshold between Room 1 and Room of the Pithoi, destroyed in Late Minoan I b (PK 63, BB, Trench 1).

\section{St-1265. Palaikastro 3}

$$
3450 \pm 75
$$

Town site in East Crete. From a rubbish pit in a pocket in the rock, filled with charcoal, bones, and some pottery of late Middle Minoan III date.

\section{Dendra series}

Carbonized figs in catastrophe layer (ashy deposit) from end of Mycenaean III B in acropolis of Midea from Dendra (Argolis) Greece (37 $30^{\prime} \mathrm{N}$ 
Lat, $23^{\circ} \mathrm{E}$ Long). Sample was treated with acetic acid before submittance. Coll. and subm. by the excavator, Paul Åström.

\section{St-1267. Dendra specimen 1 (A)}

Without laboratory pretreatment.

St-1549. Dendra specimen 1 (B)

With normal pretreatment.

\section{St-1209. Kalopsida}

Charcoal from Kalopsida, Cyprus ( $35^{\circ} 07^{\prime} \mathrm{N}$ Lat, $33^{\circ} 56^{\prime} \mathrm{E}$ Long) lation to dated potsherd layer known, but not stated by collector. Subm. by E. Gjerstad, Ist. Svedese, Rome, Italy.

\section{Miscellaneous (GEOChemical) SaMples}

\section{Southern Baltic series}

Investigation made in order to find error in $\mathrm{C}^{14}$ analysis of postglacial marine clays, especially at the coast of Blekinge. Activity figures, as $\Delta$, are age corrected but not $\mathrm{C}^{13}$ corrected. Samples are not influenced by the atomic bomb explosions. Subm. by Björn Berglund, Dept. of Quaternary Geol., Univ. of Lund.

\section{St-1467. Chara horrida \\ St-1468. Chara aspera$$
-10-16 \pm 10
$$$$
-10-4 \pm 7
$$$$
\sigma \mathrm{C}^{13}, \% \circ \quad \Delta, \%
$$

Algal samples St-1467 and St-1468 were collected $1888-1896$ by L. J. Wahlstedt in Valjeviken and Sölvesborgsviken ( $56^{\circ} 4^{\prime} \mathrm{N}$ Lat, $14^{\circ} 35^{\prime} \mathrm{E}$ Long), Blekinge, at a depth of 0.5 to $2 \mathrm{~m}$.

$$
\text { St-1469. Ulva Lactuca } \quad-10 \quad-9 \pm 15
$$
shore.

Coll. 1910 to ca. 1917 by D. Hylmö at the SW coast of Scania, near the

$$
\text { St-1474. Fucus vesiculosus } \quad-16 \quad-21 \pm 8
$$

Coll. 1936-1939 by T. Levin at Karlshamn, Ronneby and Tjurkö, on S coast of Blekinge at a depth of 0 to $5 \mathrm{~m}$.

\section{St-1517. Zostera marina $\quad-13 \quad-14 \pm 7$}

Seawood coll. 1900 at Torhamnsfjärden $\left(56^{\circ} 4^{\prime} \mathrm{N}\right.$ Lat, $15^{\circ} 50^{\prime} \mathrm{E}$ Long $)$, Långöra, Blekinge, probably at a depth of 2 to $4 \mathrm{~m}$. Seawood is used as insulation in a small house at the island Långöra. Comment (B.E.B.) : results of the $\mathrm{C}^{13}$ analysis correspond well with Wickman's (1958) investigations of submarine plants. The activity seems to be higher in plants from southern Baltic in comparison with plants from the ocean coasts (cf. Stockholm V, Kristineberg series from $W$ coast of Sweden). 


\section{Thucholite series}

Mineral pitch and thucholite; carbonaceous matter collected in fissure zones in Archean bedrock exposed in iron mines in central Sweden. Purpose of investigation is to disclose if the bitumen has been formed after the Quaternary glaciation. Coll. and subm. by E. Welin, Atomic Energy Co., Stockholm.

St-1410. Kvarntorp, kerogen $>40,000$

St-1411. Kvarntorp, kolm > $>38,000$

St-1408. Grängesberg, mineral pitch $>40,000$

St-1409. Nullaberget, thucholite ("huminite") $>\mathbf{3 8 , 0 0 0}$

St-1412. Stripa, thucholite

$30,300+1120$ 28,350 в.c.

St-1415. Samsala, thucholite

$31,650+1320$

26,960 в.с.

St-1417. Zinkgruvan, thucholite

$>38,000$

St-1416. Boliden, thucholite

$>40,000$

St-1414. Kallmora, mineral pitch

$>40,000$

St-1413. Nyängsgruvan, mineral pitch

$>40,000$

\section{Jotunheimen series}

Humus layers apparently redeposited by wind, in snowbanks and other ice near glaciers, from the Jotunheimen area in Norway. Coll. 1963 by J. Låg and Gunnar Östrem, Univ. of Stockholm; subm. by Gunnar Östrem.

St-1364. Smådalen 0-2 cm

From $61^{\circ} 43^{\prime} \mathrm{N}$ Lat, $08^{\circ} 50^{\prime} \mathrm{E}$ Long. Material was dried and sifted through a $0.5 \mathrm{~mm}$ standard sieve in order to remove young organic fibres.

\section{St-1365. Smådalen 5-10 cm}

At same location as St-1364, similarly dried and sifted.
$1475 \pm 80$ A.D. 475

$$
385 \pm 70
$$

A.D. 1565

Surface layer of humus on a dry, sandy glacio-fluvial deposit in Veodalen valley $\left(61^{\circ} 38^{\prime} \mathrm{N}\right.$ Lat, $08^{\circ} 40^{\prime} \mathrm{E}$ Long).

\section{St-1367. Veodalen $428-12 \mathrm{~cm}$}

$$
2615 \pm 70
$$

Sample taken at same location as St-1367, but at a lower level. Comment: similar datings from high mountain regions have not been made previously. Result shows that decomposition of humus is far slower in the cold climate of such areas than in the lowlands. 


\section{Tarfala glacier series}

Samples of upper part of soil outside the end-moraines taken in order to date the humus-particles in the soil $\left(67^{\circ} 56^{\prime} \mathrm{N}\right.$ Lat, $18^{\circ} 40^{\prime} \mathrm{E}$ Long). Samples were taken in walls of a small pit, and material was sieved through a $0.5 \mathrm{~mm}$ standard sieve. Coll. and subm. 1964 by Gunnar Östrem.

\section{St-1537. Tarfala glacier, $3-5 \mathrm{~cm}$}

$3815 \pm 80$

Humus at 3 to $5 \mathrm{~cm}$ depth.

\section{St-1536. Tarfala glacier, $5-8 \mathrm{~cm}$}

1865 в.c.

Humus at 5 to $8 \mathrm{~cm}$ depth.

\section{St-1535. Tarfala glacier, $15-20 \mathrm{~cm}$}

Humus at 15 to $20 \mathrm{~cm}$ depth.

$4965 \pm 120$

3015 B.c.

\section{Baffin Island series}

Samples of wind-transported soil particles from ice found in ice-cored moraines. The organic material (pollen, leaf fragments, etc.), originating from ground vegetation, was separated from the ice by melting and sedimentation. Age of the organic matter is supposed to be somewhat higher than moraine ridge where material was found. Coll. and subm. by Gunnar Östrem.

\section{St-1329. Ice Ridge Moraine A}

$12,540 \pm 360$

10,590 в.c.

After a 5 day's sedimentation period, the meltwater was siphoned off and the sediment dried and sifted through a $1 \mathrm{~mm}$ standard sieve in order to remove gravel and stones. From $70^{\circ} \mathrm{N}$ Lat, $74^{\circ} 20^{\prime} \mathrm{W}$ Long.

\section{St-1338. Ice Ridge Moraine B}

$11,910 \pm 140$

9960 в.c.

Sample taken at same location as $\mathrm{St}-1329$, but the sedimentation period was accelerated to 1 day by adding salt $(\mathrm{NaCl})$ to the meltwater.

Date lists:

REFERENCES

Stockholm I Östlund, 1957h

Stockholm II Östlund, 1959

Stockholm III Östlund and Engstrand, 1960

Stockholm IV Engstrand and Östlund, 1962

Stockholm V Östlund and Engstrand, 1963

Uppsala I Olsion, 1959

Uppsala II $\quad$ Olsson, 1960

Ambrosiani, B., 1964, Fornlämningar och bebyggelse: Uppsala, Sweden, Almqvist and Wiksells printing office.

Engstrand, L. G., and Östlund, H. G., 1962, Stockholm natural radiocarbon measurements IV: Radiocarbon, v. 4, p. 115-136.

Frödin, G., 1954, De sista skedena av Centraljämtlands glaciala historia: Geographica, v. 24, p. $1-251$

Hagherg, U.-E., 1961, Skedemosse-en första presentation: Fornvännen, v. 56, p. 237-255 (summary in German).

- 1962, Fiskekatsan idag och för 3500 år sedan: Tor, v. 8, p. $229-243$ (summary in German).

1963, Blotare i Skedemosse: Tor, v. 9, p. 114-162.

1964, Järnålderns offerfynd ur svenskt perspektiv: Tor, v. 10, p. 222-239. 
Högbom, A. G., 1893, Om interglaciala aflagringar i Jemtland: Sveriges Geol. Undersökning, ser. C, no. 128, and Geol. Fören., Stockholm Förh., v. 15, p. 28-44.

Kulling, O., 1945, On the find of mammoth at Pilgrimstad in Jämtland (in Swedish, summary in English ): Sveriges Geol. Undersökning, ser. C, no. 473.

Lundqvist, G., 1959, C 14-dated pine stumps from the high mountains in western Sweden (in Swedish, summary in English ): Sveriges Geol. Undersökning, ser. C., no. 565.

Nilsson, T., 1935, Die pollenanalytische Zonen gliedung der spät- und postglacialen Bildungen Schonens: Geol. Fören., Stockholm Förh., v. 57, p. 385-562. 1961, Ein neues Standardpollendiagram aus Bjärsjoholmssjön in Schonen: Lunds Universitets Årsskrift, v. 56, no. 18.

Olsson, Ingrid, 1959, Uppsala natural radiocarbon measurements I: Am. Jour. Sci. Radioc. Supp., v. 1, p. 87-102. 1960, Uppsala natural radiocarbon measurements II: Am. Jour. Sci. Radioc. Supp., v. 2, p. 112-128.

Östlund, H. G., 1957, Stockholm natural radiocarbon measurements I: Science, v. 126, p. $493-497$. Supp., v. 1, p. 35-44.

Östlund, H. G., and Engstrand, L. G., 1960, Stockholm natural radiocarbon measurements III: Am. Jour. Sci. Radioc. Supp., v. 2, p. 186-196. p. $203-227$. p. $271-278$.

Stenberger, M., 1960, Gravfältet vid sockenmötet. Dragby i Skuttunge, orientering och problem: Tor, v. 6, p. $63-86$.

Sundius, N., and Sandegren, R., 1948, Interglacialfyndet vid Långsele: Sveriges Geol. Undersökning, ser. C, no. 495.

Wickman, F. E., 1952, Variations in the relative abundance of the carbon isotopes inplants: Geochimica et Cosmochimica Acta, v. 2, p. 243-254. 